\title{
Max Müller, Charles Darwin and the science of religion
}

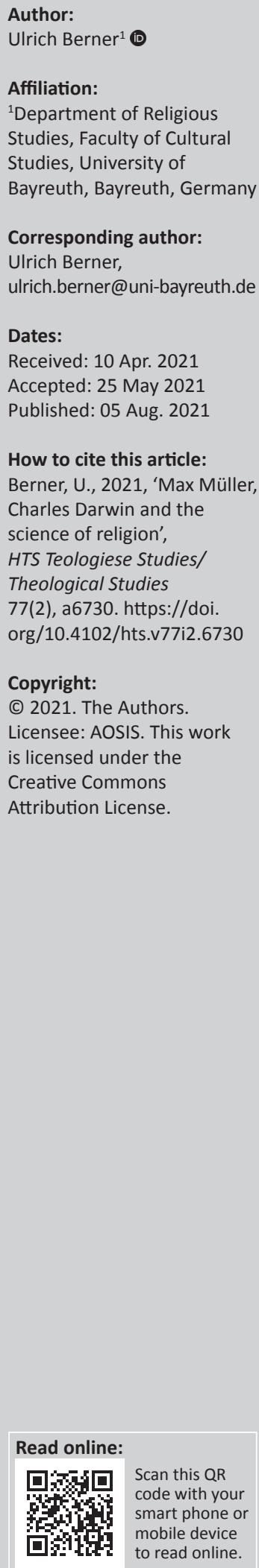

The science of religion, as a discipline distinct from theology emerging in the 19th century, from the beginning was closely related to the discourse on Darwinism. This article focusses on Max Müller, known as 'The father of Comparative Religion', who was involved in the Darwinian discourse, compared with Jane Ellen Harrison who emphasised the impact of the theory of evolution, approaching, however, the 'scientific study of religion' from a different viewpoint.

Contribution: From a historical point of view, this article discusses the relationship between different strands in Religious Studies (Religionswissenschaft), and, also, touches upon the relationship between Religious Studies and Theology.

Keywords: Darwinism; comparative religion; theology; Max Müller; Jane E. Harrison.

When Jane Ellen Harrison, known as an expert on Greek religion, gave a talk on 'The Influence of Darwinism on the Study of Religions', she revealed to the audience that the title of her paper might well have been 'The Creation by Darwinism of the Scientific Study of Religions' (Harrison 1915:143). Although she had changed the title, in order to avoid 'any shadow of exaggeration', she insisted that the new view on religion - regarding it as 'a proper subject for scientific study' - was made 'possible, and even necessary' by the doctrine of evolution (Harrison 1915:143/144). As representatives of this new view on religion, making it a proper object of scientific study, she mentioned, amongst other names, E.B. Tylor and J. G. Frazer (Harrison 1915:151). The fact that she does not refer in any way to Max Müller, who is widely known as the 'Father of Comparative Religion' (Sharpe 1991:35; cf. Cox 2006:73) or even as 'the founder of the modern scientific study of religion' (Wiebe 1998:11), may raise astonishment, the more so, as he had for decades been involved in the discourse on Darwinism, even corresponding with Charles Darwin himself (Müller 1902:477f., 503f., 523f.).

Research on the debate between Max Müller and Charles Darwin has focussed on the topic of language as 'the barrier between brute and man' (see Ambasciano 2019:46f.; Kippenberg 2002:40; Van den Bosch 2000, 2002:185-189). It is true that Müller's explicit discussions on Darwin's theory of evolution centred on the question of language, insisting that speech 'is a specific faculty of man' and 'distinguishes man from all other creatures', which seems to imply that he would totally reject Darwin's theory on the descent of man (Müller 1861:360; cf. Müller 1887:94). So, at first sight, it seems reasonable to assume that Müller's conception of the new 'Science of Religion', as he used to designate the new discipline, was constructed just in opposition to Darwinism, and therefore, being outside the scope of Harrison's description of the new view on religion that is 'created' by Darwinism or, at least, based on the doctrine of evolution.

Müller, however, has on several occasions expressed his high esteem for Darwin and his scientific work: 'Darwin certainly brought much that is beautiful and true to the light of day' (Müller 1903:54; cf. 1887:103). He did not hesitate to take up the concept of evolution, contending that he had been an 'evolutionist' before Darwin, as all languages have undergone and keep undergoing processes of evolution: '[h]ow a student of the Science of Language can be anything but an evolutionist, is to me utterly unintelligible' (Müller 1887:89). As he is known for constructing the science of religion 'after the model of the science of language' (Müller 1869:XI; cf. Müller 1870:5 $1898: 225,262 \mathrm{f}$.), it is hardly conceivable that the theory of evolution did not have any influence on his approach to the study of religion. What may be relevant in this context is the fact, easily overlooked, that Müller distinguished between Darwin's original conception - with special regard to his attitude towards religion - and Darwinism, which is the conception of evolution as

Note: Special Collection: Re-readings of Major Theorists of Religion: Continuities and Discontinuities, sub-edited by Mohammed (Auwais) Rafudeen (University of South Africa). 
interpreted by Darwin's followers, as, for instance, Ernst Haeckel (Müller 1887:106f.). So, it seems rewarding to have a fresh look at the emergence of Müller's programme of a 'science of religion', in relation to the emergence of Darwinism in 19th century Britain and Europe. This means that his writings on religion have to be related to the discourses on Darwin's main works published in 1859 and 1871.

In 1858, before the beginning of a Darwinian discourse, Müller wrote a review of 'Christ and other Masters' by Charles Hardwick, a 'Christian Advocate in the University of Cambridge'. This review does not yet develop the programme of a 'science of religion', as distinct from theology. When opposing 'the tone of offended orthodoxy' he found in Hardwick's book, Müller's answer remains within the framework of a theological discourse, stating (Müller 1869):

[T]hat it has pleased God to let these men and millions of human beings be born on earth without a chance of ever hearing of the existence of the gospel. (p. 53)

Also, adding in the next sentence that:

[W]e cannot penetrate into the secrets of the Divine wisdom, but we are bound to believe ..., ... that He will know how to judge those to whom so little has been given. (p. 53)

His emphasis on an historical approach, however, might be seen as foreshadowing the programme of an independent science of religion, ' $[w]$ e must do what the historian does. We must become ancients ourselves; otherwise we shall never understand the motives and meaning of their faith' (Müller 1869:56). The programme of the new science of religion is elaborated some years later, in the preface to the first volume of 'Chips from a German Workshop', which includes the review mentioned above (Müller 1869:XIX-XXVII).

After the publication of Darwin's 'Origin of Species', Müller immediately began discussing the theory of evolution and would continue discussing it till the end of his life. In the very first lecture on the 'Science of Language', he revealed the main elements of his worldview, which he kept defending in all his later works: his contention is that 'nothing exists in nature by accident', and that 'there are laws which underlie the apparent freedom and variety of all created things'; these laws, in Müller's view, 'indicate to us the presence of a purpose in the mind of the Creator' (Müller 1861:18; cf. Müller 1887:98, 1903:57). Trying to show that this faith - the firm belief that there is a divine order in the universe - is not alien to nor incompatible with science, he refers to Copernicus and Kepler who combined this kind of faith with the hard and successful - scientific work of collecting data (Müller 1861:19f.).

Trying to position himself in the Darwinian discourse, Müller discussed in great detail what animals and humans have in common. He gave a long list, stating that animals 'have sensation, perception, memory, will, and intellect', and even admitting that instinct is a common element of animals and humans - so, it is not a Cartesian view of animals as mechanistic automata (Müller 1861:363, 364-367). He insists, however, that there is one decisive difference: Language is, in his view, 'our Rubicon, and no brute will dare to cross it', and without it, abstract thinking would be impossible (Müller 1861:367; cf. Van den Bosch 2000).

Therefore, it is only man's reason that is 'conversant with general ideas', and so '... we not only stand a step above the brute creation; we belong to a different world'. (Müller 1861:396). Thus, it seems the more reasonable that Jane Harrison did not mention Müller when speaking about the influence of Darwinism on the new approach to the study of religion. At first sight, Müller's worldview seems to be incompatible with Darwinism. It should be noted, however, that he had made great efforts to take over from Darwin's theory as much as possible by emphasising that human nature shares many traits with animals.

After his first reaction to Darwin's work, Max Müller kept reflecting on the theory of evolution, obviously reading Darwin's book again and again, even comparing the different editions and noting the changes. Thus he discovered that Darwin himself in a later edition had inserted the notion of a Creator - in the very last sentence of 'On the Origin of Species' (Müller 1887:106; Darwin 1959:759). Although he could not ignore the fact that Darwin did not claim for the Creator 'more than that He created a few original forms' (Müller 1889:226), he felt authorised to take this as Darwin's concession that there is 'a beyond', a position distinct from the materialistic worldview of certain Darwinians: '[y]es, Darwin himself would be ashamed of his followers, for he saw, though not always clearly, that everything in this sphere presupposes something beyond, ...' (Müller 1903:31; cf. Müller 1889:257f.). Also, Darwin's religious self-definition as an 'agnostic' in Müller's view indicated some common ground:

[A]gnosticism, in the true sense of the word, is the only possible, ..., and I may add, the only Christian position, which the human mind can occupy before the Unknown and the Unknowable. (Müller 1887:107; cf. Müller 1892:102f.)

His essay 'Why I am not an agnostic' does not contradict this argument, but actually is in line with it. For he declares to be 'an Agnostic, ..., in relying on nothing but historical facts and in following reason as far as it will take us in matters of the intellect'; he would be 'a Gnostic' only in case 'Agnosticism' would be understood as excluding 'a recognition of an eternal reason pervading the natural and the moral world' (Müller 1901:355f.).

Now it is becoming clear to which extent Müller was willing to accept and appropriate Darwin's theory and which aspect he would keep opposing during a lifelong discussion. His basic intention was to defend a teleological worldview, as he could not bring himself to view nature as chaotic, natural processes driven by chance alone, not leading to 'premeditated forms' (Müller 1887:98; 101f.; cf. Müller 1901:351, 355, 1903:57). 
When he kept insisting that language is 'the barrier between the brute and man', his basic intention was only to refute the theory that 'every mute animal may in time become man', depending on the chance and circumstances. Thus it appears he would be ready to admit that man might have been a mute animal in the past, if only the idea of purpose and plan in nature would be maintained (Müller 1887, 89; cf. 113). He could accept a theory of evolution that would recognise '[b]road [1]ines', keeping different processes of development apart, leading from different points of origin to different results (Müller 1887:93-102). This version of a theory of evolution he traced back to German theologian-philosopher Johann Gottfried Herder, introducing him as 'the Darwin of the eighteenth century' and contending that his ideas had still been influential in 19th-century Germany, mentioning without going into details, Schelling, Goethe and Hegel (Müller 1889:261; 264). Certainly, Darwin would not have consented to this understanding of evolution. It cannot be denied, however, that by inserting the notion of a 'Creator' and by defining himself as an '[a]gnostic', Darwin had opened the door for such a kind of interpretation and appropriation of his theory.

Müller's conception of a 'science of religion', it appears, emerged like Harrison's 'scientific study of religion', in the context of a Darwinian discourse, integrating the theory of evolution, although in a modified version. The question arises, if Müller's new discipline, like Harrison's, could be classified as being or at least leading towards a 'scientific study of religion', clearly distinct from theology. According to Lourens Van den Bosch, Müller's science of religion was 'essentially a theological discipline in the service of divine truth' (Van den Bosch 2002:356). Robert Segal has given a similar assessment, classifying Müller as 'a Religionist' like Mircea Eliade, thus comparing him with the most controversial figure of the History of Religions in the 20th century (Segal 2016:136; Ambasciano 2019:117; cf. Berner 2007:37). Donald Wiebe had given a different assessment, contending that 'a careful reading reveals his proposed science of religion to rest wholly upon a scientific rather than a religio-theological foundation' (Wiebe 1998:11). Leonardo Ambasciano seems to agree with this assessment, emphasising Müller's 'scientific ethos' (Ambasciano 2019:48).

At first sight, the classification as a theological discipline seems to be correct, as it is undeniable that Müller's work was apologetic, of religion, in general - offering a 'safeguard against atheism' (Müller 1891:333) - and of Christianity, in particular, as he did not hide his conviction that it is the best religion (see, for instance, Müller 1892:388, 1893:26). For instance, even in his 'Introduction to the Science of Religion', delivered in 1870, after a decade of Darwinian discourses, Müller apparently continued arguing within a theological framework, contending that Christianity alone has taught us 'to discover the traces of a divine wisdom and love in the government of all the races of mankind', and quoting St. Peter's statement that 'God is no respecter of persons' (Müller 1870:10; 52). In addition, he postulated in this work a special 'faculty of faith in man', a 'mental faculty', which 'independent of, nay, in spite of sense and reason, enables man to apprehend the Infinite ...' (Müller 1870:5). Having established 'in man a third faculty', he goes on to divide the science of religion into two parts, surprisingly taking up the notion of theology, distinguishing between 'Comparative' and 'Theoretic Theology' (Müller 1870:6, 49). There are, however, some aspects in his work that should be taken into consideration before classifying his science of religion as being 'essentially theological'.

In his lectures on 'The Origin and Growth of Religion', delivered in 1878, after the publication of Darwin's 'The Descent of Man', Müller seems to have changed his approach to some extent. At the beginning, he declares that the science of religion is 'as little a modern invention as religion itself', that it would not begin with Feuerbach but with ancient Greek philosophers, as, for instance, Thales 'who protested against the religion of the crowd', and Heracleitos, who was already reflecting upon the origin of religion (Müller 1898:7f.). The reference to Feuerbach and Heracleitos seems to indicate a wide horizon of his science of religion, encompassing more than just apologetics. And the Darwinian concept, although not occurring in the title of these lectures, is taken up and applied to religion 'as something which has passed, and is still passing through an historical evolution' (Müller 1898:21). And, what is most significant, Müller now denies explicitly 'that there is a separate consciousness for religion'; now he considers only 'sense and reason' as functions of the 'conscious self' (Müller 1898:21f.). Looking back to his earlier lectures of 1870, he makes some efforts to redefine the concept of '(mental) faculty' in such a way as to make it fit into his new conception that restricts the sources for religious ideas to senses and reason: now he contends that religious knowledge must pass 'through these two gates', explicitly excluding the notions of 'primeval revelation' or 'religious instinct' from any explanation of the origin of religion (Müller 1898:22f.; 226; 381; cf. Ambasciano 2019:48). A decade later, in his first course of Gifford Lectures, he would insist that '[r]eligion, ..., must, like all other knowledge, begin with sensuous experience' (Müller 1889:114; cf. Green 2016:184). This move may be interpreted as a final effort to free his 'science of religion' from theology.

The programme of the Gifford Lectures, as defined by the founder of this famous lectureship, to which Müller was invited several times, apparently confirms this interpretation (cf. Wiebe 1998:23). This programme stipulated that the lecturer could and should be appointed irrespective of his religious affiliation: he could be 'of any religion or of no religion' and could be a 'freethinker' or a 'skeptic' (Müller 1889:X). By consenting to this programme without any reservation or objection, Müller was indeed freeing the science of religion from theology, in the sense that he would not confine it to a religious enterprise - religion could be studied from different worldviews, religious or non-religious. This is decisively different from a position, which maintains that the study of religion presupposes personal religious commitment, 
a position allegedly held by Rudolf Otto and the phenomenologists of religion (cf. Berner 2016:55-57). Although presenting himself as believing in the truth of religion - his belief being based on the universality of religion - Müller would not hesitate to admit the possibility that in spite of its universality, religion might be a hallucination. In this case, he insisted, almost anticipating a modern cognitive approach, 'an accurate knowledge of the causes and the different phases of this universal disease might prove useful for its final cure' (Müller 1892:92; cf. Müller 1898:174; Wiebe 1998:16). In any case, whether truth or hallucination, the science of religion, he would insist, should be given a place amongst 'other historical studies' in the university (Müller 1892:91).

The objection might be raised that Müller's approach is incoherent, as he continued to argue within a theological framework, even in his final Gifford Lectures quoting sentences from the New Testament and presenting them as true as, for instance, Acta 14, 17: 'God did not leave himself without witness' (Müller 1893:6; cf. 23). His consent to this teaching of Paul, however, is not a theological statement in a strict sense, as it is the result of historical research on nonChristian religions. The history of the religions of the world has to provide 'evidence' for the truth of Paul's teachings, which implies that those teachings do not have to be accepted as articles of faith if such evidence is missing. When positioning himself in a theological discourse such as this one, concerning the relationship between Christianity and other religions, Müller argues by referring to 'facts'. Often, he would draw upon the religious history of India, as, for instance, when reconstructing the 'Biography of Agni' in order to 'show how the human mind, unassisted by what is called special revelation, found its way ... to the highest concept of a supreme and invisible God' (Müller 1893:6; cf. Müller 1891:ch. VI-VIII). This assertion would imply that Christianity is just one of many religions, including African religions (cf. Berner 2004:142-145), not having a higher status based on a special revelation.

His assessment of Christianity as the best religion (Müller 1873:37f., 1893:26, 538, 541), however, seems to contradict this assertion, the more so as he had used notions like 'final victory' or 'Holy War of mankind' in his speech 'On Missions' (Müller 1874:49, 53; cf. 66). It has to be kept in mind, however, firstly, that he stated explicitly that 'other religions also contain all that is necessary for salvation' (Müller 1891:364); secondly, that his understanding of Christianity is a very personal one, not bound to any creed or dogma of one or the other denomination: ' $[t]$ he endless theological discussions ... not yet ended in the nineteenth century ..., have fortunately no interest for us' (Müller 1892:385). For instance, he does not take any notice of the dogmatic decisions in the fourth century. Instead, he goes back to the 'earliest ante-Nicene authorities, the true Fathers of the Church' (Müller 1901:344) and, ultimately, to the 'simple utterances of Christ' in the New Testament, first of all in the gospel of John (for instance, Jn 1,12). There he finds 'the discovery of the Divine in man', or the 'recognition of a divine element in man' (Müller 1892:380, 384). As he would not claim any exclusivity for
Christianity, he was open for seeing an equivalent of this highest religious discernment in the Upanishads and the Vedanta philosophy (cf. Green 2016:189; Van den Bosch 2002:479f.). The metaphors of 'father' and 'son', as found in the New Testament, in Müller's view were just the best means of 'expressing the relation between the Divine in man and the Divine in nature'. Thus, he could, on the one hand, 'hold that Christianity has given the best and truest expression of what the old world had tried to express in various and less perfect ways'; on the other hand, he could admit, probably thinking of the Upanishads and Vedanta, 'that there are certain philosophies which have entered more deeply into this problem of the Divine in man or the immortality of the soul than any religion' (Müller 1892:388, 390).

Again, it appears that Müller's assessment of Christianity as the best religion is not a theological statement in a strict sense. He emphasises, referring to his comparative studies, that he has 'at least given the facts' on which his assessment is based, and he adds explicitly, 'If my facts can be proved to be wrong, my conclusions will fall; ...' (Müller 1892:388). By declaring his work open to criticism pertaining to facts and to logic only (Müller 1887:543, 1892:391), his science of religion obtains a position apart from theology. For the religious commitment, faith or belief, as confessed and propagated by Müller, is derived from and remains dependent on the comparative historical study of religions, a position most theologians of any tradition probably would regard as inappropriate. Also, it seems not very likely that (Christian) theologians would regard his interpretation of Christianity as acceptable; from a History of Religions point of view, however, it is totally legitimate just as one of many versions of this religious tradition.

With regard to the different strands of theology in the 19th century, the question might be raised if he would have approved of a new kind of scientific theology as coming close to his science of religion - one could think of the 'Religionsgeschichtliche Schule' emerging in the late 19thcentury Germany (cf. Berner 1988:217-224). In fact, Müller followed with interest a trial for heresy in the Anglican Church: the case of Bishop John William Colenso who had applied a critical historical method to Biblical Studies, drawing upon recent works of German theologians (see Colenso 1862:XIVXVI; cf. Draper 2003). Müller (1902) was in full agreement with this critical theological approach, saying in a letter:

[T] he time will come when they will thank Colenso for having shown that the Old Testament is a genuine old book, full of all the contradictions and impossibilities which we have a right to find in old books .... (p. 495)

And, indeed, Bishop Colenso's theology intersects with Müller's science of religion, as is visible, for instance, in his applying 'the same measure' when comparing the phenomena of Christianity with other religions (cf. Berner 2012:143f.).

Parts of Müller's work have rightly been criticised and fallen into oblivion (cf. Van den Bosch 2002:491). This critique would 
concern, firstly, his hermeneutics of myths (cf. Kippenberg 2002:48f.; Lincoln 1999:67); secondly, his overall neglect of the 'social and ritualistic dimensions of religion' (Van den Bosch 2002:357). Indeed, when talking about prayers, for instance, he is always inclined to isolate them from their ritual context, as he is interested only in religious ideas (see, for instance, Müller 1889:243f., 521, 1891:106-109). With regard to his presentation of 'facts', critique would have to be raised against his use of notions, such as 'silly', 'childish' or 'error' (see, for instance, Müller 1873:335f.; 1891, 102, 328; cf. Freiberger 2019:47). Also, critique would have to be raised against his 'conclusions' - violating the rules of logic which he himself declares 'holy', by taking the universality of a belief as the 'proof' for its truth (Müller 1891:331, 1892:92-96). Finally, another starting point for critical reflections would be the fact that his scholarly work 'often depended upon the resources and intersected with the interests of the British Empire' (Chidester 2014:61; cf. Chidester 2004; Swamy 2019:725).

It is not necessary to give more details about shortcomings and mistakes in Müller's work. It should not be forgotten, however, that he was carrying out pioneer work, when he tried to free the study of religion from the commitment to one religious tradition or denomination, that is, from theology as it was traditionally defined. He did not hesitate to admit that a real 'science of religion' was 'as yet a promise rather than a fulfillment', expressing his trust that 'which at present is but a desire and a seed, will in time become a fulfillment ...' (Müller 1870:9, 1898:385). The question remains, however, where to find this fulfillment in the 20th century - in the History of Religions (Religionswissenschaft) or in (pluralistic or interreligious) Theology? For an answer to this question, his first course of Gifford Lectures, perhaps, provides the best point of departure: lecture IX offers a 'Historical Treatment of Religious Questions', and the following one a 'Comparative Study of Religious Problems'. It appears that there are two options for the classification of Müller's 'science of religion', taking either the questions he would discuss or the treatment he would apply, as the decisive criterion.

At first sight, these titles might be indicating that Müller's 'science of religion' is an 'essentially theological discipline' (Van den Bosch 2002:356), as it is clearly the task of theology to deal with religious questions and problems, as, for instance, 'the possibility of a revelation' (Müller 1889:233; cf. Müller 1892:V). Also, Müller states at the beginning that the 'burning question of the day is not what religion has been, ...'; the 'real question', he says, 'is the possibility of any religion at all' (Müller 1889:221). Again, it seems, he enters the field of theological discourses. The intention to discuss 'burning questions of the day', however, needs not be confined to theology, as there may be a demand in the society for information independent of any religious institution and tradition. Participation in the public discourse on religion, concerning, for instance, the compatibility with Darwinism, might be regarded as a legitimate or even central task of the scientific study of religion too. Participating in a public discourse, however, does not necessarily imply taking up the role of 'the scholar of religion as public intellectual', as defined by Russell T. McCutcheon and contested by Donald Wiebe (see McCutcheon 1997:452f.; Wiebe 2005:8-10). A less known work 'The Silesian Horseherd. Questions of the Hour Answered by Friedrich Max Müller' is a good example of such a public discourse.

As a contributor to a periodical that had a worldwide circulation, like the Deutsche Rundschau, Max Müller often received letters 'from every corner of the earth' (Müller 1903:40), and in this case, he had decided to respond to the letter sent by a German emigrant to America who had signed as 'ein schlesisches Pferdebürla' (Silesian Horseherd). This anonymous person had read Müller's essay on secondcentury philosopher Celsus, a critic of Christianity. Referring to Hume and Schopenhauer, he challenged Müller by stating his opinion that 'after these heroes positive Christianity would be an impossibility'. As he reports about his disappointment when attending the World's Parliament of Religion at Chicago, it seems reasonable to assume that this 'horseherd' would not have been interested in discussing with a professional theologian of one or the other religious tradition. After some time, Max Müller decided to publish the correspondence, 'in the hope that there are other "Pferdebürle" in the world to whom it may be of value' (Müller 1903:43). Thus, it appears, he was acting like a 'public intellectual', although in a wider sense.

Although the questions he discussed in his public lectures belong to the subject matter of theology, it is clear that the treatment was borrowed or taken over from non-theological disciplines, and this could be taken as the decisive criterion for assessing his 'science of religion' as resting 'on a scientific rather than a religio-theological foundation' (Wiebe 1998:11). It appears that this assessment is confirmed when looking at Müller's (1889) modest claim: having chosen for his own task 'a careful study of the historical development of religious thought ...,' he declares:

[I] claim for it at first no more than that it may serve at least as a useful preparation for the final solution of the different problems the great philosophers have laid before us. (p. 222)

Not surprisingly, in this context he mentions Darwin and elaborates on 'agnosticism' (Müller 1889:222). And in the following lecture, he repeated this modest claim for the comparative study of religion to be 'the best preparation for the study of what is called the philosophy of religion', adding that it 'activates and invigorates our mind, and produces that judicial temper which is so essential in the treatment of religious problems' (Müller 1889:274). The very concept of 'preparation' indicates an awareness that there is a borderline between historical or comparative studies and theology or philosophy of religion.

In any case, it is not necessary to follow Müller in taking the final step, from historical and comparative studies to a belief in the truth - or falsity - of religious thoughts. As Müller does never hide his personal beliefs and convictions - in this 
respect, he differs from a 'religionist' like Eliade, and he makes it possible for the reader to use the 'facts' drawn from the various religious traditions without taking over the conclusions transgressing the border of historical research. An example of such a critical reception is the philosophy of Friedrich Nietzsche, a famous critic of Christianity, who made an extensive use of Müller's work (Figl 2007:229-236). As the basic assumptions of Müller's approach do not include the belief in a primeval or any special revelation, it may be regarded as being or at least leading to the new discipline of a scientific study of religion, in spite of its one-sided emphasis on discussing religious ideas. Tracing the history of ideas in various religious traditions and noting intra- and intercultural differences and similarities are useful endeavours in itself if only the space remains open for drawing conclusions into different directions and worldviews: religious and nonreligious. The narrow focus on religious ideas, however, makes it necessary to look for other complementary approaches that would stress the social character of religion, cult and ritual in particular. Such an approach was realised by Jane Harrison and the 'Cambridge Ritualists' (cf. Ackerman 1991:1-3; Schlesier 1990:134).

In contrast to Max Müller, Jane Harrison did not have any problem consenting to the 'doctrine of evolution', without any reservations or modifications. And she did not see the need for differentiating between Darwin and Darwinism, nor to discuss the various meanings of 'agnosticism'. She was not interested in discussing the compatibility of Darwinism and religious ideas, simply declaring that 'theology must go' (Harrison 1915:179; cf. 207), in contrast to Max Müller who had consented at least to some theological teachings of the 'ancient Fathers of the Church' (Müller 1869:XXVIII-XXX; cf. Müller 1901:344). Thus she would deal just with those religious phenomena that Max Müller had neglected, that is, the social aspect in general and ritual in particular: ' $t$ the first preliminary to any scientific understanding of Greek religion is a minute examination of its ritual' (Harrison 1903:VII).

Jane Harrison's (1915) theory about the origin of religion was influenced by Durkheim, whose 'doctrine' she found 'persuasively stated' by her friend and colleague F. Cornford:

$[R]$ eligion is not the aspiration of the individual soul after a god, or after the unknown, or after the infinite; rather it is the expression, utterance, projection of the emotion, the desire of a group. (p. 50)

This concept of religion focusses just on that aspect which Max Müller was not interested in; it could be seen just as the counter thesis to Müller's concept of religion defined as the human perception of the Infinite, leading from physical to psychological religion (see, for instance, Müller 1889:164, 188, 1892:93f., 393). Whilst Müller saw the essence of human nature in abstract thinking - ' $[\mathrm{m}] \mathrm{an}$ means the thinker, ...', and (only) man asks the question, '[w]hence comes this world?' (Müller 1869:X, 1889:244), Harrison would say '[m]an is at first too busy living to have any time for disinterested thinking', and the 'religious impulse', according to her, is directed 'primarily to one end and one only, the conservation and promotion of life' (Harrison 1915:157, 1962:XVII). Thus, ritual becomes the central object of the 'scientific study of religion', as worship is prior to belief in a god, not the other way round as people used to assume: man '... worships, he feels and acts, and out of his feeling and action, projected into his confused thinking, he develops a god' (Harrison 1915:161; cf. Brunotte 2001:9f.).

For interpreting this divergence in the approaches to the study of religion, Harvey Whitehouse's 'Modes of Religiosity' theory may be used as a starting point. According to Whitehouse, there are two modes: the imagistic and the doctrinal one (Whitehouse 2000:9-12). Harrison's interest was primarily directed towards those phenomena that would fall under the category of the 'imagistic mode', as, for instance, the Greco-Roman Mystery-cults containing 'rites charged with suggestion, with symbols, with gestures, ..., with all the apparatus of appeal to emotion and the will;...' (Harrison 1915:175; cf. Berner 2009:35-37). Max Müller, like Jane Harrison, was not interested in the doctrinal mode, even pointing critically to the intolerance of the Church (Müller 1892:385). However, he was not interested in the imagistic mode either. Thus it seems necessary to define a third mode of religiosity, which might be designated as the 'gnostic mode', referring to Müller's discussion of (a)gnosticism and his emphasis on 'knowledge' as distinct from dogma: taking the parable of the king's son, who grew up as the son of a shepherd, as an example, he tries to make clear that the decisive religious experience - of the divine sonship of all humans - consists in knowledge. In the parable, the son becomes a prince by getting to know that the king is his father: '[t]o know is here to be, to be to know' (Müller 1892:383; cf. Müller 1903:208).

In spite of these differences in their approaches - related to different conceptions of evolution and agnosticism, there are some basic assumptions they have in common: Max Müller would have fully agreed with Jane Harrison's (1915) statement that it is:

$[B] y$ thinking of religion in the light of evolution, not as a revelation given, $\ldots$, but as a process, $\ldots$, that we attain to a spirit of real patience and tolerance. (p. 177)

Müller's science of religion was based just on that principle religion as process, not as a revelation given - and it was certainly aiming at a spirit of tolerance: 'to agree to differ is the best lesson of the comparative science of religion' (Müller 1903:216). Thus, it appears that these two divergent approaches should not be seen as incompatible but as complementary, each one correcting the other's onesidedness. The 'scientific study' or 'science' of religion as distinct from theology could well be defined just as encompassing both these approaches, emerging in the encounter with Darwinism, but focusing on different phenomena and pursuing different agendas.

With regard to the development of the discipline in the 20th century, the same argument could be applied: phenomenological and social-scientific approaches to the 
study of religions should not be seen as incompatible but as complementary. The phenomenology of religion has been criticised severely, and rightly so, for its decontextualising tendency (cf. Lincoln 2018:19). However, phenomenological concepts, as, for instance, 'sacred space', could still function as useful descriptive categories, if the social context of religious phenomena is taken into consideration (cf. Berner 2020:24-27). Zimbabwean scholar of Religion, Kupakwashe Mtata (2017), in his study on the Matobo National Park, has given such a contextualising analysis of sacred spaces.

\section{Acknowledgements Competing interests}

The author declares that they have no financial or personal relationships that may have inappropriately influenced them in writing this article.

\section{Author's contributions}

U.B. is the sole author of this research article.

\section{Ethical considerations}

This article followed all ethical standards for research without direct contact with human or animal subjects.

\section{Funding information}

This research received no specific grant from any funding agency in the public, commercial or not-for-profit sectors.

\section{Data availability}

Data sharing is not applicable to this article as no new data were created or analysed in this study.

\section{Disclaimer}

The views and opinions expressed in this article are those of the author and do not necessarily reflect the official policy or position of any affiliated agency of the author.

\section{References}

Ackerman, R., 1991, 'The Cambridge group: Origins and composition', in W.M. Calde (ed.), The Cambridge ritualists reconsidered, pp. 1-19, Scholars Press, Atlanta, GA.

Ambasciano, L., 2019, An unnatural history of religions: Academia, post-truth and the quest for scientific knowledge, Bloomsbury Academic, London.

Berner, U., 1988, 'Religionswissenschaft und theologie. Das Programm de Religionsgeschichtlichen Schule', in H. Zinser (ed.), Religionswissenschaft. Eine Einführung, pp. 216-238, Dietrich Reimer Verlag, Berlin

Berner, U., 2004, 'Africa and the origin of the science of religion: Max Mülle (1823-1900) and James George Frazer (1854-1941) on African religions', in F. Ludwig/A. Adogame (eds.), European traditions in the study of religion in Africa, pp. 141-149, Harrassowitz Verlag, Wiesbaden.

Berner, U., 2007, 'Mircea Eliade and the myth of Adonis', in B. Rennie (ed.) The international eliade, pp. 37-46, State University of New York Press, Albany, NY

Berner, U., 2009, 'The imagistic tradition of dionysos in the Graeco-Roman world', in L.H. Martin/P. Panayotis (eds.), Imagistic traditions in the Graeco-Roman world: A cognitive modeling of history of religious research, pp. 35-53, Vanias Editions, Thessaloniki.

Berner, U., 2012, 'Religiosität und Rationalität. Reginald Scot und die Kritik des Hexenglaubens in der Frühen Neuzeit', in U. Berner/J. Quack (eds.), Religion und Kritik in der Moderne, pp. 141-179, LIT Verlag, Berlin.
Berner, U., 2016, 'Gegenstände der Religionswissenschaf: Phänomene und/oder Symbolsysteme?', in K. Lehmann/A. Jödicke (eds.), Einheit und Differenz in der Religionswissenschaft. Standortbstimmungen mit Hilfe eines Mehr-EbenenModells von religion, pp. 53-74, Ergon-Verlag, Würzburg.

Berner, U., 2020, 'Mountains as sacred spaces', Culture and Religion 21(1), 18-30. https://doi.org/10.1080/14755610.2020.1858545

Brunotte, U., 2001, 'Das Ritual als Medium, göttlicher Gemeinschaft. Die Entdeckung des Sozialen bei Robertson Smith und Jane Ellen Harrison', in E. Fischer-Lichte/ Horn, Chr./S. Umathum/M. Warstat (eds.), Wahrnehmung und Medialität, pp. 85-101, A. Francke Verlag, Tübingen.

Chidester, D., 2004, “"Classify and conquer”: Friedrich Max Müller, indigenous religious traditions, and imperial comparative religion', in J.K. Olupona (ed.), Beyond primitivism. Indigenous religious traditions and modernity, pp. 71-88, Routledge, New York, NY.

Chidester, D., 2014, Empire of religion. Imperialism and comparative religion, University of Chicago Press, Chicago, IL.

Colenso, J.W., 1862, The Pentateuch and book of Joshua critically examined, Longman, Green, Longman, Roberts, \& Green, London.

Cox, J.L., 2006, A guide to the phenomenology of religion. Key figures, formative influences and subsequent debates, T \& T Clark International, London.

Darwin, C., 1959, On the origin of species. A variorum text, in M. Peckham (ed.), University of Pennsylvania Press, Philadelphia, PA.

Draper, J.A., 2003, 'The trial of Bishop John William Colenso', in J.A. Draper (ed.), The eye of the storm: Bishop John William Colenso and the crisis of biblical inspiration, pp. 306-325, Cluster Publications, Pietermaritzburg.

Figl, J., 2007, Nietzsche und die Religionen. Transkulturelle Perspektiven seines Bildungs- und Denkweges, De Gruyter, Berlin.

Freiberger, O., 2019, Considering comparison. A method for religious studies, Oxford University Press, New York, NY.

Green, T.J., 2016, 'Vedantist of vedantists?' The problem of Friedrich Max Müller's religious identity, Publications of the English Goethe Society, vol. LXXXV, pp. 180-190.

Harrison, J.E., 1903, Prolegomena to the study of Greek religion, Cambridge University Press, Cambridge.

Harrison, J.E., 1915, Alpha and omega, Sidgwick \& Jackson Ltd., London.

Harrison, J.E., 1962, Epilegomena to the study of Greek religion and Themis. A study of the social origins of Greek religion, University Books, New York, NY.

Kippenberg, H.G., 2002, Discovering religious history in the modern age, Princeton University Press, Princeton, NJ.

Lincoln, B., 1999, Theorizing myth. Narrative, ideology, and scholarship, The University of Chicago Press, Chicago, IL.

Lincoln, B., 2018, 'The future of history of religions (with Cristiano Grottanelli)', in B. Lincoln (eds.), Apples and oranges. Explorations in, on, and with comparison, pp. 14-24, The University of Chicago Press, Chicago, IL.

McCutcheon, R.T., 1997, 'A default of critical intelligence? The scholar of religion as public intellectual', Journal of the American Academy of Religion 65(2), 443-468. https://doi.org/10.1093/jaarel/65.2.443

Mtata, K., 2017, Religion and nature in Africa. The case of Matobo National Park, Zimbabwe, and its vicinities. Diss. phil. (Bayreuth International Graduate School of African Studies), Bayreuth.

Müller, F.M., 1861, Lectures on the science of language, Delivered at the Royal Institution of Great Britain in April, May, \& June, 1861, Oriental Publishers and Booksellers (5th reprint 1965), Delhi.

Müller, F.M., 1869, Chips from a German workshop. Volume I Essays on the science of Religion, (Scholars Press Chico California Reprint 1985), Charles Scribner and Company, New York, NY.

Müller, F.M., 1870, Introduction to the science of religion, Spottiswoode and Co., London. Müller, F.M., 1874, On missions, Scribner, Armstrong, and Company, New York, NY.

Müller, F.M., 1887, The science of thought, Longmans, Green, and Co., London.

Müller, F.M., 1889, Natural religion, The Gifford Lectures 1888, Longmans, Green, and Co., London.

Müller, F.M., 1891, Physical religion, The Gifford Lectures 1890, Longmans, Green, and Co., London.

Müller, F.M., 1892, Anthropological religion, The Gifford Lectures 1891, Longmans, Green, and Co., London.

Müller F.M., 1893, Theosophy or psychological religion, The Gifford Lectures 1892, Longmans, Green, and Co., London.

Müller, F.M., 1898, Lectures on the origin and growth of religion as illustrated by the religions of India, The Hibbert Lectures 1878, Re-Issue, Longmans, Green, and Co, London.

Müller, F.M., 1901, 'Why I am not an agnostic', in F.M. Müller (eds.), Last essays, Second Series, Essays on the science of religion, pp. 346-356, Longmans, Green, and Co., London.

Müller, F.M., 1902, The life and letters of the Right Hounorable Friedrich Max Müller, edited by his wife, Vol. II, Longmans, Green, and Co., New York, NY.

Müller, F.M., 1903, The Silesian Horseherd (Das Pferdebürla). Questions of the hour answered by Friedrich Max Müller, Longmans, Green, and Co., London.

Schlesier, R., 1990, 'Jane Ellen Harrison. 9 September 1850 - 15 April 1928', in W.W. Briggs \& W.M. Calder III (eds.), Classical scholarship, pp. 127-141, Garland Publishing, Inc., New York, NY.

Segal, R.A., 2016, Friedrich Max Müller on religion and myth, Publications of the English Goethe Society Vol. LXXXV, pp. 135-144. 
Sharpe, E., 1991, Comparative religion. A history, 2nd edn., Open Court, LaSalle, IL. Swamy, M., 2019, 'Revisiting the antecedents of interreligious dialogue', The Ecumenical Review 71(5), 718-738. https://doi.org/10.1111/erev.12475

Van den Bosch, L.P., 2000, 'Language as the barrier between brute and man. Friedrich Max Müller and the Darwinian debate on language', Saeculum 51(1), 57-89. https://doi.org/10.7788/saeculum.2000.51.1.57

Van den Bosch, L.P., 2002, Friedrich Max Müller. A life devoted to the humanities, Brill, Leiden.
Whitehouse, H., 2000, Arguments and icons. Divergent modes of religiosity, Oxford University Press, Oxford.

Wiebe, D., 1998, 'Religion and the scientific impulse in the nineteenth century: Friedrich Max Müller and the birth of the science of religion', in D. Wiebe (ed.), The politics of religious studies. The continuing conflict with theology in the academy, pp. 9-30, St. Martin's Press, New York, NY.

Wiebe, D., 2005, 'The politics of wishful thinking? Disentangling the role of the scholarscientist from that of the public intellectual in the modern academic study of scientist from that of the public intellectual in the modern academic
religion', Temenos 41(1), 7-38. https://doi.org/10.33356/temenos.4800 